\title{
The contribution of geochemical and mineralogical characterization of iron slags in provenance studies in the Podravina region, NE Croatia
}

\author{
Tomislav Brenko ${ }^{1, *}$, Tena Karavidović2 ${ }^{2}$ Sibila Borojević Šoštarić ${ }^{1}$ and Tajana Sekelj Ivančan² \\ 1 University of Zagreb, Faculty of Mining, Geology and Petroleum Engineering, Department of Mineralogy, Petrology and Mineral Resources, \\ Pierottijeva 6, 10000 Zagreb, Croatia; ( ${ }^{*}$ corresponding author: tomislav.brenko@rgn.unizg.hr) \\ 2 The Institute of Archaeology, Jurjevska ulica 15, 10000 Zagreb, Croatia
}

doi: $10.4154 / g c .2022 .11$

Article history:

Manuscript received November 15, 2021

Revised manuscript accepted January 05, 2022

Available online January 31, 2022

Keywords: iron production, XRD, ICP-MS/AES trace elements, NRC ratios, $\mathrm{PCA}$, bog iron ore

\begin{abstract}
Archaeological excavations in the Podravina region led to discovery of sites with traces of bloomery iron production during Late Antiquity and the Early Middle Ages. Mineralogical analysis of the slags recognized fayalite as the main mineral phase, while geochemical analysis confirmed high Fe contents, typical for bloomery iron smelting. Based on the previously established occurrences of bog iron ores in the study area, provenance studies were carried out using trace and rare earth elements to create a geochemical signature. Similar shapes and patterns of bog iron ores and iron slag signatures imply a genetic connection between the ore and the slag, as well as variation related to the temporal and spatial context of both slags and ores.
\end{abstract}

\section{INTRODUCTION}

In ancient times, iron was one of the most valuable materials, and whole cultures relied upon iron production that was utilised to create an array of different objects. The main method for production of iron in pre-industrial times was the smelting of iron ores via a direct reduction process, in order to obtain an iron bloom. The metallurgical principle in this method relies on the chemical reduction of iron oxide(s) and oxyhydroxide(s) present in the iron ore by carbon or gases formed during smelting (PLEINER, 2000). During the smelting process, carbon monoxide (CO) from charcoal reacts with iron oxide(s)/oxyhydroxide(s) from the ore, forming iron particles and carbon dioxide $\left(\mathrm{CO}_{2}\right)$ (CHARLTON et al., 2010). Air could have been blown into a furnace through blowing holes/tuyeres incorporated in the furnace walls to elevate the temperature and improve the bloom formation. Additional material in the form of fluxes could have been added during the process to enhance iron gain and to lower melting temperatures (CHARLTON et al., 2012). Compounds such as silica, aluminium and unreduced iron partition from the iron as a liquid phase solidifying at the bottom of the furnace, forming furnace bottom slag (FBS) or they are discharged from the furnace, forming tap slag (TS) (PORTILLO-BLANCO et al., 2020). Textural characteristics of slag are depended on the cooling conditions, while the mineralogical and geochemical composition of smelting slags depends on the raw material used (ore, charcoal, furnace walls), potential use of flux materials (carbonates) and the way the process was carried out (air input, ratio of ore:charcoal etc.).

In the study area of the Podravina region, several sites with traces of iron production and processing were excavated (SEKELJ IVANČAN \& KARAVIDOVIĆ, 2021) while over 150 potential sites were identified through field surveys (VALENT, 2021). Bog iron ores were also detected on some sites within an archaeological context and during surface field surveys (BRENKO et al., 2021), implying that they were potentially utilised for iron production. Iron ores, and especially bog iron ores (KACZOREK \& SOMMER, 2003), are never formed purely from iron oxides/oxy- hydroxides (RAMANAIDOU \& WELLS, 2014), but rather as a combination of iron oxides/oxyhydroxides and aluminosilicate soil phases. The combination of heterogenous iron ore, with the possible addition of flux materials, charcoal and furnace lining during smelting, significantly complicates provenance studies. However, recent studies regarding the usage of major and trace elements (including rare earth elements) indicate the potential for following the geochemical signature from the iron ore to the iron slag (HORSTMADSEN \& BUCHWALD, 1999, CREW, 2000; COUSTURES et al., 2003; SCHWAB et al., 2006; DESAULTY et al., 2009). Major element analysis is used as a first discriminator of the smelting process using Non-Reduced Compounds (NRC) ratios (DILLMAN \& L'HÉRITIER, 2007). By comparing major element ratios in iron slags, it is possible to distinguish different ore sources. However, $\mathrm{NRC}$ ratios are only useful in limited cases when there are some significant differences among the ore deposit sites.

Therefore, special attention must be given to the differentiation of elements between the solid and liquid phases during smelting, especially the trace elements. Trace elements that prefer to remain in the solid phase (bloom) are termed compatible, while trace elements that go into the liquid phase (slag) are termed incompatible, as they are incompatible in the crystal structure and will try to partition at the first available opportunity, i.e. during smelting when high temperatures are introduced into the system (ROLLINSON, 1993). According to studies undertaken by COUSTURES et al. (2003) and DESAULTY et al. (2009), it can be deduced that the majority of incompatible elements will pass into the slag during the smelting process. DESAULTY et al. (2009) concluded that the enrichment factor of incompatible elements is close to their modal factor, meaning that their ratios should remain constant from the ore to the slag. A similar observation was previously made by COUSTURES et al. (2003) where plotting pairs of incompatible elements that have the same number of electrons and an equivalent ionic radius revealed that the incompatible pairs should retain the same ratios between the ore and the slag. Despite the fact that the slag can contain traces of iron particles from the bloom, due to their small size and low 
quantities it can be considered that their effect on the overall trace element content in the slag is negligible.

Considering these aspects, this paper has two main aims: (i) defining the mineralogical and geochemical characteristics that can lead to determining temporal and spatial variation in tap and furnace bottom slags from three sites dated to the Late Antiquity and Early Middle Ages and (ii) constructing the geochemical signature of iron slags to compare it to the local bog iron ores. In order to do that, two different slag sample types were analysed using geochemical and mineralogical methods. To establish the prove- nance of the studied iron slags, the geochemical signature using 26 selected trace elements and rare earth elements (REEs) was established for all slag samples. Geochemical signatures of slags are compared to the geochemical signatures of previously analysed bog iron ores found in the study area (BRENKO et al., 2021).

\section{GEOLOGICAL AND ARCHAEOLOGICAL SETTINGS}

The archaeological sites related to iron production from which the slag and ore samples originate are dated to the Late Antiquity

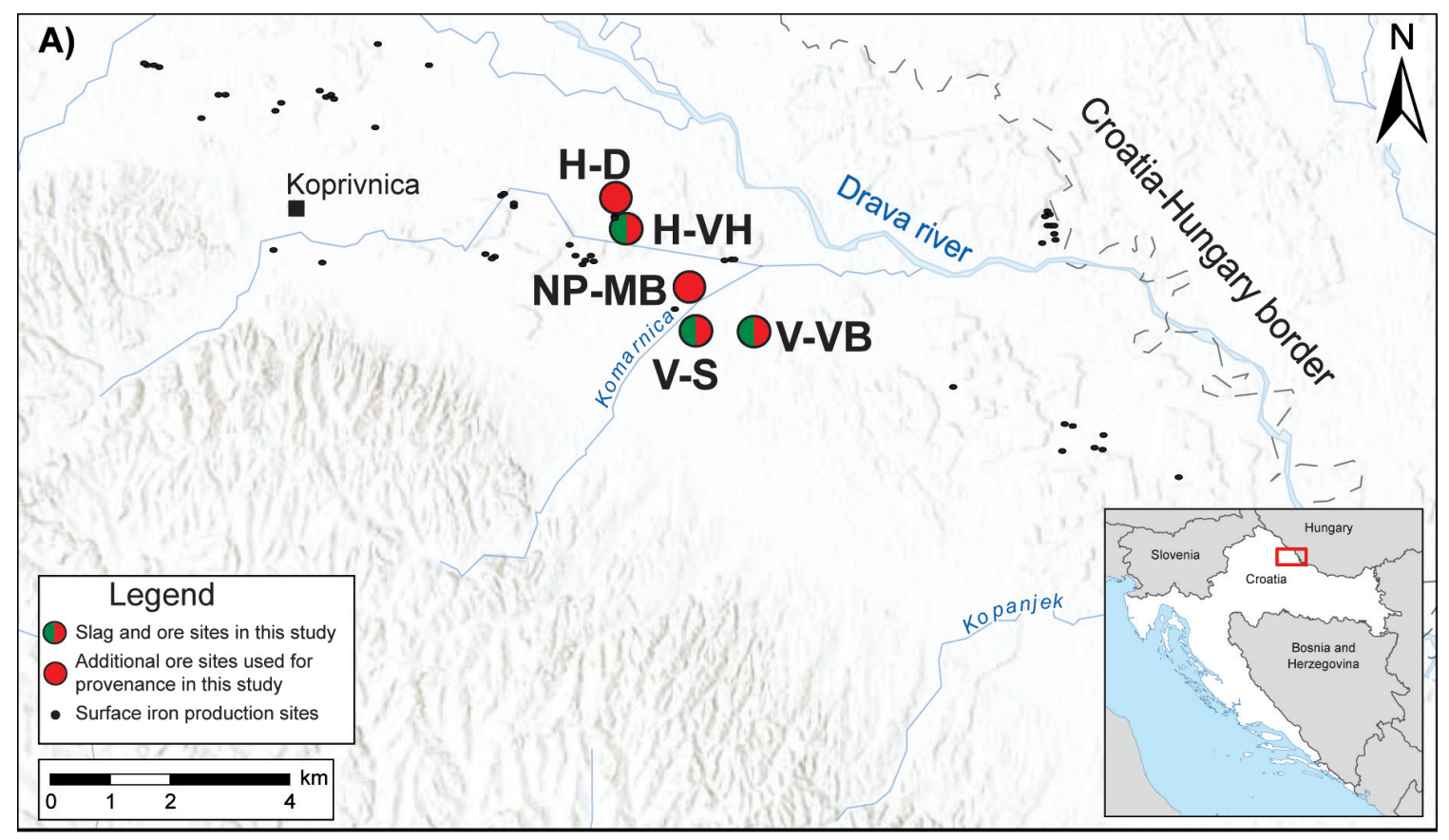

B)

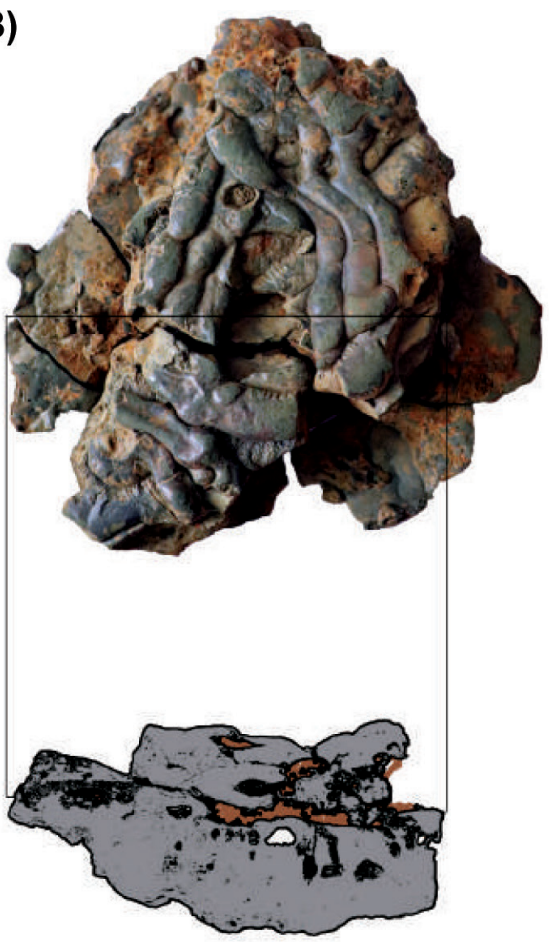

C)

rust

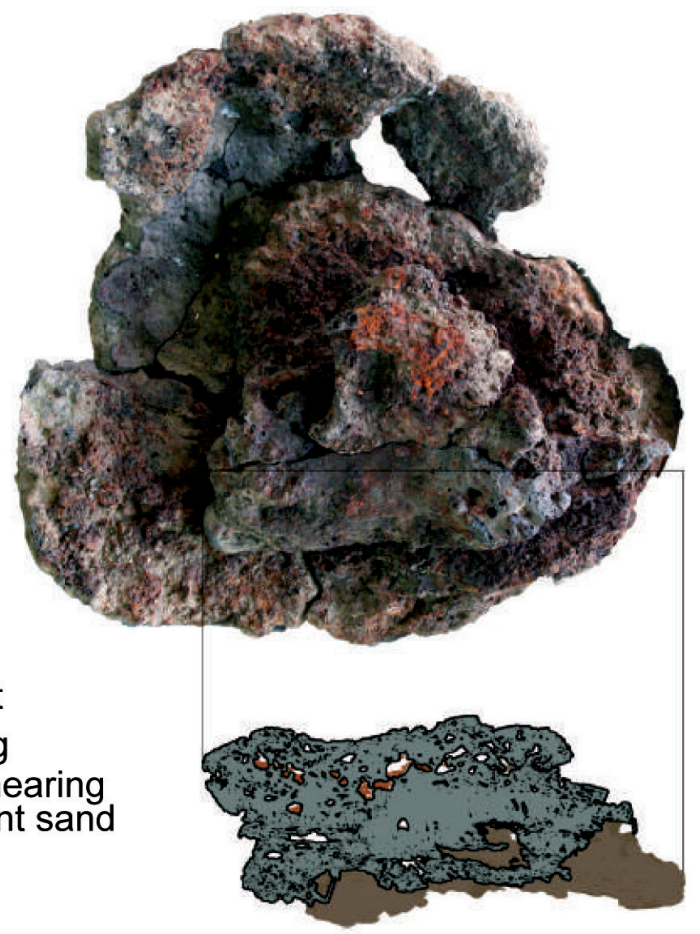

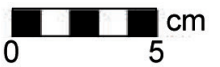

Figure 1. A) Map of the study area with locations of iron slags and iron ores used in this study. Typical morphology of B) tap slags and C) furnace bottom slags in the study area. 
and Early Middle Ages, from the $4 / 5^{\text {th }}$ (Virje-Sušine), 5/6 $6^{\text {th }}$ century (Virje-Volarski breg), as well as to the end of the $6^{\text {th }}$ and mid$7^{\text {th }}$ century (Virje-Sušine, Hlebine-Velike Hlebine) and to the end of the $8^{\text {th }}$ and the beginning of the $9^{\text {th }}$ centuries (Virje-Volarski Breg). Individual sites Virje-Volarski Breg and Virje-Sušine have several positions, where archaeological trenches were set on the basis of prior geophysical research, through which the area saturated with iron production debris was presumed. On all of the excavated positions traces of bloomery iron production workshops (SEKELJ IVANČAN \& KARAVIDOVIĆ, 2021) were discovered. The basic technological solution, in terms of the type of furnace used, was similar on all sites. The furnaces were freestanding, with a shallow hearth from which the slag was tapped out during the smelting procedure. The shaft was built entirely of clay, saturated with sand to some degree. The sites are all located in the central part of the lowland Podravina region (Croatia), on a linear distance between $0.7-7 \mathrm{~km}$ (Fig. 1). The most prominent geographical feature in the area is the meandering Drava River. Surrounding the river is the low-lying terrain of three alluvial river terraces. The river valley formed during the last Holocene climatic warming period (HEAD, 2019), where constant floods resulted in the deposition of a variety of flood sediments, including gravels, sands and silts (LÓCZY et al., 2014). Hydrological (BRKIĆ et al., 2010; BRKIĆ \& BRIŠKI, 2018) and hydrochemical (KOPIĆ et al., 2016) studies discovered that the groundwater table is close to the surface, with the aquifer system often showing elevated contents of iron and manganese. The majority of soils in the study area are determined as Fluvisols and Gleysols (BAŠIĆ, 2013). The combination of shallow groundwater enriched with iron results in the formation of bog iron ore in the study area (BRENKO et al., 2021), a sedimentary accumulation of iron and accompanying elements formed in soils due to the precipitation of iron in intervals with higher oxygen concentration (RAMANAIDOU \& WELLS, 2014).

\section{MATERIALS AND METHODS}

In this study, 33 iron slag samples (Table 1) were selected and analysed. Samples can be categorized in two main slag groups: furnace bottom slags (FBS) and tap slags (TS). From each site,

Table 1. Mineral composition of selected tap slags and furnace bottom slags in the Podravina region. Mineral abbreviations: Ank - ankerite; Dol - dolomite; Fay - fayalite; Gth - goethite; Hem - hematite; Lct - leucite; Mag - magnetite; PI - plagioclase; Px - pyroxene; Spl - spinel; Wus - wüstite; $10 \AA ̊ / 14 \AA ̊$ clay - phyllosilicates with 001 peaks at 10 or $14 \AA$.

\begin{tabular}{|c|c|c|c|c|c|c|c|c|c|c|}
\hline Sample & $\begin{array}{l}\text { Trench / SU / } \\
\text { Sample nr. }\end{array}$ & Site & Age & Fay & Qz & Gth & Hem & Mag & Wüs & Other minerals \\
\hline H-VHTS 1 & 1/38B/133 & \multirow{13}{*}{$\begin{array}{l}\text { Hlebine - Velike } \\
\text { Hlebine }\end{array}$} & \multirow{13}{*}{$\begin{array}{c}\text { 6-7th } \\
\text { century }\end{array}$} & +++ & - & - & - & + & + & Spl \\
\hline H-VHTS 2 & 1/37A/1/137 & & & +++ & $?$ & - & - & - & + & Spl, Dol (?) \\
\hline H-VHTS 3 & $1 / 37 A / 1 / 140$ & & & +++ & $?$ & - & - & - & - & Spl, Dol (?) \\
\hline H-VHTS 4 & 2/113/266 & & & +++ & + & + & - & - & $?$ & PI, Stishovite (?) \\
\hline H-VHTS 5 & 2/113/270 & & & +++ & + & - & - & - & - & $\operatorname{Px}(?)$ \\
\hline H-VH TS 6 & $2 / 109-110 / 251$ & & & +++ & $?$ & - & - & - & - & Spl \\
\hline H-VHTS 7 & $2 / 109-110 / 251$ & & & +++ & $?$ & - & - & - & - & Spl (?) \\
\hline H-VH TS 8 & 2/97/98/ & & & +++ & + & - & - & - & $?$ & / \\
\hline H-VHTS 9 & $2 / 65 / 169$ & & & +++ & - & - & - & - & + & Spl \\
\hline H-VH FBS 1 & $1 / 38 \mathrm{~A} / 135$ & & & +++ & $?$ & $?$ & - & - & + & Spl, Px (?) \\
\hline H-VH FBS 2 & 1/37A/144 & & & +++ & + & - & - & - & ++ & / \\
\hline H-VH FBS 3 & 1/37A/1/137 & & & +++ & + & - & - & - & - & Px, $10 \AA ̊$ clay (?) \\
\hline H-VH FBS 4 & $1 / 001 / 25 / 36$ & & & +++ & + & - & - & - & + & $\operatorname{Px}(?)$ \\
\hline V-STS 1 & 7/327/432 & \multirow{10}{*}{ Virje - Sušine } & \multirow{7}{*}{$\begin{array}{c}\text { 4-5th } \\
\text { century }\end{array}$} & +++ & + & - & - & - & + & Spl \\
\hline V-STS 2 & 7/327/427-1 & & & +++ & + & - & - & - & ++ & Px \\
\hline V-STS 3 & $7 / 314 / 295-1$ & & & +++ & $?$ & - & - & - & ++ & I \\
\hline V-STS 4 & 7/317/305/ & & & +++ & + & - & - & - & ++ & $\operatorname{Px}(?)$ \\
\hline V-STS 5 & 7/314/295-7 & & & +++ & $?$ & - & - & - & - & I \\
\hline V-STS 6 & $7 / 314 / 295-14$ & & & +++ & + & - & - & - & + & Spl (?) \\
\hline V-S FBS 1 & 5/237/126 & & & ++ & + & $?$ & - & - & ++ & Lct \\
\hline V-STS 7 & $5 / 270 / 125$ & & \multirow{3}{*}{$\begin{array}{c}6-7 \text { th } \\
\text { century }\end{array}$} & +++ & + & - & - & - & - & Spl (?), PI \\
\hline V-STS 8 & $5 / 217 / 124$ & & & +++ & + & $?$ & + & - & - & PI, Px (?) \\
\hline V-STS 9 & $5 / 240 / 115$ & & & ++ & + & - & - & - & - & Px, 10Å clay (?) \\
\hline V-VB TS 1 & $3 / 191 / 55$ & \multirow{10}{*}{$\begin{array}{c}\text { Virje - Volarski } \\
\text { Breg }\end{array}$} & \multirow{9}{*}{$\begin{array}{l}5 / 6-7 \text { th } \\
\text { century }\end{array}$} & +++ & $?$ & - & - & - & - & Spl (?) \\
\hline V-VB TS 2 & $2 \mathrm{a} / 138 / 140$ & & & +++ & + & $?$ & - & - & + & Spl \\
\hline V-VB TS 3 & $2 \mathrm{a} / 138 / 140$ & & & +++ & $?$ & - & - & - & ++ & Spl \\
\hline V-VB FBS 1 & $3 / 201 / 74$ & & & +++ & + & - & - & - & ++ & Spl, Px (?) \\
\hline V-VB FBS 2 & $3 / 201 / 80$ & & & +++ & + & + & - & - & ++ & Spl, Px (?) \\
\hline V-VB FBS 3 & $3 / 187 / 54$ & & & +++ & + & - & - & - & + & Spl, Lct \\
\hline V-VB FBS 4 & 3/001/180/56a & & & +++ & $?$ & - & - & - & - & Spl, Lct \\
\hline V-VB FBS 5 & $3 / 001 / 180 / 56 b$ & & & +++ & + & + & - & - & ++ & $\operatorname{Px}(?)$ \\
\hline V-VB FBS 6 & $2 a / 173 / 51$ & & & ++ & $?$ & ++ & + & - & ++ & Ank \\
\hline V-VB FBS 7 & $1 / 38 / 95$ & & $\begin{array}{c}\text { 8-9th } \\
\text { century }\end{array}$ & ++ & ++ & + & - & - & + & $\mathrm{Pl}, 10 \AA ̊$ / 14Å \\
\hline
\end{tabular}

+- relative abundance of minerals based on X-ray diffraction (no quantitative value assigned to + ) ++++ major component, ++ minor component; + traces; ? - not enough diffraction peaks to fully confirm 
both slag types were selected and analysed (Fig. 1B and C). The main objective of sample selection was to take into consideration samples from temporally and spatially different sites, as well as samples of different types of slag generated through the bloomery smelting process in order to compare their composition to local bog iron ores from archaeological and/or geological contexts.

In order to acquire a reliable mineralogical and geochemical dataset, a slate from the cross section of each sample was cut using a circular saw. By doing so, homogenization was ensured, and potential sampling of rusted or adhering clayey or sandy materials was avoided. Each slate was air-dried at room temperature for several days, removing excess moisture and then homogenized to powder fraction using a vibratory mill for several minutes in a steel grinding set. The mineralogical composition was determined by X-ray powder diffraction (XRD) using a Phillips

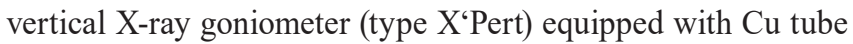
and graphite crystal monochromator. Scan settings were $3-70^{\circ}$ $2 \theta, 0.02^{\circ}$ step size, 1 second count time per step while generator settings were $40 \mathrm{kV}$ and $35 \mathrm{~mA}$. Semi-quantitative mineral identification was conducted using PANalytical X'Pert HighScore software with standardised Powder Diffraction Files (PDF) of the International Centre for Diffraction Data (ICDD) (Newton Square, PA, USA) and by comparing peak shapes and heights with internal standards for quartz, feldspars and clay minerals, while fayalite, wüstite and other Fe mineral contents were estimated based on geochemical data. The geochemical composition, including the main oxides, major-, micro- and REEs was determined in MSALabs (Langley, Canada). Multielement contents of trace and REEs were analysed using inductively coupled plasmamass spectrometry (ICP-MS), while 4-acid digestion including hydrochloric, nitric, perchloric and hydrofluoric acids was used for near total digestion. Only the most highly resistant minerals could possibly remain not fully dissolved. Based on two internal standards, several blanks and duplicates, instrumental precision was between $3-5 \%$ and the detection limits for most analysed elements were in the part per million (ppm) or lower bracket. Major oxide contents were determined using inductively coupled plasma-atomic emission spectrometry (ICP-AES) with lithium borate fusion. Loss on ignition (LOI) was determined by weight difference after ignition at $1000{ }^{\circ} \mathrm{C}$.

This approach using trace elements and REEs was undertaken in the provenance studies of iron slags in the Podravina region. Based on the behaviour of the 26 selected elements, it is believed that the geochemical signature of the discovered iron slags could be traced back to ore used for archaeological iron production in the region. To supress the Oddo-Harkins effect and to

Table 2. Chemical composition of selected iron slags in the Podravina region. All values for major oxides and LOI given in mass. \%.

\begin{tabular}{|c|c|c|c|c|c|c|c|c|c|c|c|c|}
\hline Sample & Location & $\mathrm{SiO}_{2}$ & $\mathrm{TiO}_{2}$ & $\mathrm{Al}_{2} \mathrm{O}_{3}$ & $\mathrm{Fe}_{2} \mathrm{O}_{3}$ & $\mathrm{MgO}$ & $\mathrm{MnO}$ & $\mathrm{CaO}$ & $\mathrm{K}_{2} \mathrm{O}$ & $\mathrm{Na}_{2} \mathrm{O}$ & $\mathrm{P}_{2} \mathrm{O}_{5}$ & LOI \\
\hline H-VHTS 1 & \multirow{13}{*}{$\begin{array}{l}\text { Hlebine - Velike } \\
\text { Hlebine }\end{array}$} & 22.52 & 0.24 & 4.51 & 65.36 & 0.53 & 0.79 & 1.09 & 0.59 & 0.29 & 0.67 & -5.09 \\
\hline H-VHTS 2 & & 25.16 & 0.23 & 4.85 & 63.15 & 0.57 & 0.79 & 1.63 & 0.77 & 0.28 & 0.59 & -5.05 \\
\hline H-VHTS 3 & & 26.51 & 0.27 & 5.49 & 66.40 & 0.65 & 0.96 & 2.24 & 0.92 & 0.45 & 0.66 & -5.97 \\
\hline H-VHTS 4 & & 29.84 & 0.27 & 5.21 & 61.13 & 0.78 & 2.00 & 1.99 & 0.81 & 0.36 & 0.83 & -1.77 \\
\hline H-VHTS 5 & & 26.30 & 0.22 & 4.18 & 66.46 & 0.81 & 1.97 & 1.84 & 0.67 & 0.28 & 0.81 & -4.93 \\
\hline H-VHTS 6 & & 27.36 & 0.30 & 6.01 & 60.45 & 0.67 & 1.00 & 1.45 & 0.97 & 0.39 & 0.77 & -5.69 \\
\hline H-VHTS 7 & & 32.57 & 0.35 & 6.81 & 58.85 & 0.88 & 1.22 & 2.51 & 1.67 & 0.47 & 0.68 & -4.88 \\
\hline H-VHTS 8 & & 27.63 & 0.28 & 5.89 & 59.60 & 0.60 & 1.56 & 2.49 & 0.99 & 0.41 & 0.78 & -5.69 \\
\hline H-VHTS 9 & & 26.80 & 0.25 & 5.36 & 65.15 & 0.81 & 1.82 & 2.32 & 0.83 & 0.38 & 0.96 & -6.07 \\
\hline H-VH FBS 1 & & 25.58 & 0.22 & 4.61 & 65.35 & 0.64 & 0.85 & 1.75 & 0.74 & 0.28 & 0.61 & -4.96 \\
\hline H-VH FBS 2 & & 22.33 & 0.21 & 4.99 & 62.63 & 0.53 & 0.73 & 2.20 & 0.97 & 0.30 & 0.69 & -6.31 \\
\hline $\mathrm{H}-\mathrm{VH}$ FBS 3 & & 32.57 & 0.34 & 6.13 & 55.47 & 0.72 & 0.76 & 2.00 & 1.12 & 0.47 & 0.62 & -3.72 \\
\hline H-VH FBS 4 & & 26.64 & 0.36 & 5.10 & 62.68 & 0.67 & 0.45 & 1.66 & 1.15 & 0.51 & 0.74 & -3.14 \\
\hline V-S TS 1 & \multirow{10}{*}{ Virje - Sušine } & 25.20 & 0.19 & 4.59 & 54.43 & 0.52 & 0.99 & 1.25 & 0.82 & 0.36 & 0.88 & -6.13 \\
\hline V-STS 2 & & 29.19 & 0.29 & 5.66 & 63.12 & 0.72 & 1.02 & 3.03 & 1.07 & 0.42 & 0.94 & -5.26 \\
\hline V-S TS 3 & & 20.88 & 0.14 & 3.74 & 61.02 & 0.54 & 0.64 & 1.99 & 0.67 & 0.29 & 0.99 & -6.35 \\
\hline V-STS 4 & & 25.91 & 0.19 & 4.44 & 61.29 & 0.70 & 0.81 & 3.05 & 0.97 & 0.30 & 0.78 & -5.92 \\
\hline V-STS 5 & & 35.41 & 0.38 & 7.23 & 58.03 & 0.72 & 1.00 & 1.87 & 1.28 & 0.56 & 0.52 & -5.27 \\
\hline V-S TS 6 & & 28.92 & 0.29 & 5.72 & 64.26 & 0.50 & 1.09 & 1.16 & 0.83 & 0.47 & 0.52 & -5.77 \\
\hline V-S TS 7 & & 37.28 & 0.38 & 7.01 & 55.98 & 0.70 & 1.04 & 1.47 & 1.08 & 0.60 & 0.58 & -4.69 \\
\hline V-STS 8 & & 34.05 & 0.38 & 6.74 & 56.91 & 0.93 & 1.18 & 3.08 & 1.08 & 0.56 & 0.51 & -3.87 \\
\hline V-STS 9 & & 27.96 & 0.26 & 5.45 & 61.11 & 0.62 & 0.92 & 1.68 & 0.83 & 0.44 & 0.49 & -4.28 \\
\hline V-S FBS 1 & & 25.72 & 0.27 & 4.59 & 54.87 & 0.99 & 0.53 & 3.63 & 2.84 & 0.34 & 1.15 & -2.08 \\
\hline V-VB TS 1 & \multirow{10}{*}{ Virje - Volarski Breg } & 28.57 & 0.33 & 7.89 & 55.80 & 0.97 & 1.52 & 1.86 & 1.13 & 0.41 & 0.66 & -5.12 \\
\hline V-VBTS 2 & & 25.90 & 0.25 & 7.26 & 53.46 & 0.79 & 1.09 & 1.90 & 1.12 & 0.34 & 0.93 & -4.32 \\
\hline V-VB TS 3 & & 25.67 & 0.24 & 6.68 & 57.60 & 0.75 & 1.26 & 1.98 & 1.19 & 0.36 & 1.03 & -5.36 \\
\hline V-VB FBS 1 & & 21.19 & 0.22 & 5.95 & 55.57 & 0.86 & 1.06 & 2.64 & 0.77 & 0.27 & 1.11 & -3.35 \\
\hline V-VB FBS 2 & & 18.55 & 0.16 & 4.91 & 53.23 & 0.54 & 0.51 & 1.58 & 0.68 & 0.28 & 0.87 & -2.39 \\
\hline V-VB FBS 3 & & 25.20 & 0.33 & 8.03 & 52.30 & 1.17 & 1.36 & 1.90 & 0.86 & 0.38 & 1.24 & -0.52 \\
\hline V-VB FBS 4 & & 23.76 & 0.30 & 7.89 & 54.49 & 1.11 & 0.59 & 2.26 & 1.16 & 0.32 & 0.92 & -3.03 \\
\hline V-VB FBS 5 & & 14.56 & 0.12 & 4.10 & 61.34 & 0.51 & 0.37 & 1.53 & 0.61 & 0.22 & 0.65 & -2.33 \\
\hline V-VB FBS 6 & & 11.69 & 0.11 & 4.34 & 60.06 & 0.47 & 0.31 & 0.76 & 0.45 & 0.10 & 0.59 & 4.02 \\
\hline V-VB FBS 7 & & 27.96 & 0.27 & 5.03 & 56.49 & 0.69 & 1.06 & 1.77 & 1.09 & 0.43 & 0.73 & -1.34 \\
\hline
\end{tabular}


avoid artificial peaks in the geochemical signature of iron slags, the REEs and trace elements were normalized to Upper Continental Crust (RUDNICK \& GAO, 2003) and then plotted on the appropriate diagrams for each archaeological site. Geochemical signatures of bog iron ores are derived from the dataset in BRENKO et al. (2021), where both unroasted and roasted iron ores were analysed. The analysed ores were found in the same archaeological context as iron slags or on temporally and spatially related sites as well as in their natural geological setting, during an archaeological field survey of the wider area around archaeological sites under study (samples from Novigrad Podravski).

\section{RESULTS}

\subsection{Mineralogical and geochemical characteristics of iron slags}

Tap slags (TS) tend to be dark grey in colour with high lustre, and occasional signs of porosity. Their upper surface usually contains signs of flow texture due to their previously melted state. Furnace bottom slags (FBS) are also greyish in colour, with parts of samples being red. They tend to be slightly concave in shape due to their position at the bottom of the furnace and usually have higher porosity than TS.

Mineralogically, both TS and FBS samples contain fayalite $\left(\mathrm{Fe}_{2} \mathrm{SiO}_{4}\right)$ as the main mineral phase. Besides fayalite, all samples contain quartz in traces to moderate amounts, while wüstite (FeO) also occurs in the majority of samples as either a major or trace component. Other minerals, including iron minerals (magnetite, haematite and goethite) as well as pyroxene, spinel (hercynite) and leucite occur in trace amounts (Table 1). Additionally, slightly elevated background levels, especially noted in the VirjeVolarski breg site, point to the possible occurrence of amorphous matter, such as the glassy slag matrix.

Major oxides composition in the slags mainly consists of $\mathrm{Fe}_{2} \mathrm{O}_{3}$ ranging from 52.30 - 66.46 mas. $\%(\chi=59.52$ mas. $\%)$ and $\mathrm{SiO}_{2}$ ranging from 11.69 to 37.28 mas. $\%(\chi=26.22$ mas. $\%$ ) (Table 2). TS and FBS from the Hlebine-Velike Hlebine site have the highest $\mathrm{Fe}_{2} \mathrm{O}_{3}$ contents, with values between $55.47-66.46$ mas. $\%(\chi=62.95$ mas. $\%, n=13)$. This is followed by $\mathrm{Fe}_{2} \mathrm{O}_{3}$ contents in slags from the Virje-Sušine positions, where the contents range from $54.34-64.26$ mas. $\%(\chi=59.10$ mas. $\%, n=10)$, while slags from the Virje-Volarski Breg positions have the lowest contents, with values between 52.30 - 61.34 mas. $\%(\chi=56.03$ mas. $\%, \mathrm{n}=10$ ) (Table 2). Only $\mathrm{Al}_{2} \mathrm{O}_{3}$ with values between 3.74 - 8.03 mas. $\%(\chi=5.65$ mas. $\%, n=33)$ is present in significant quantities at all archaeological sites. Contents of $\mathrm{CaO}(0.76-3.63$ mas. $\%, \chi=1.99$ mas. $\%), \mathrm{MnO}(0.31-2.00$ mas. $\%, \chi=1.01)$, $\mathrm{K}_{2} \mathrm{O}(0.45-2.84$ mas. $\%, \chi=0.99$ mas. $\%), \mathrm{P}_{2} \mathrm{O}_{5}(0.49-1.24$ mas. $\%, \chi=0.77$ mas. $\%), \mathrm{MgO}(0.47-1.17$ mas. $\%, \chi=0.72$ mas. $\%), \mathrm{Na}_{2} \mathrm{O}(0.10-0.60$ mas. $\%, \chi=0.37$ mas. $\%)$ and $\mathrm{TiO}_{2}(0.11$ -0.38 mas. $\%, \chi=0.26$ mas. $\%$ ) are mostly present as minor components (Table 2).

NRC ratios for several major oxides are presented in Fig. 2 and compared with geochemical data from several studies from Croatia and Europe. Biplot diagrams revealed a positive linear correlation in the case of the $\mathrm{SiO}_{2} / \mathrm{Al}_{2} \mathrm{O}_{3}$ ratio with the Virje-Volarski Breg site standing out due to higher $\mathrm{Al}$ contents (Fig. 2A). $\mathrm{SiO}_{2} / \mathrm{Fe}_{2} \mathrm{O}_{3}$ and $\mathrm{Fe}_{2} \mathrm{O}_{3} / \mathrm{MnO}$ ratios show a grouping of data for all sites (Fig. 2B and 2C). Principal component analysis of the major oxide composition in iron slags resulted in ten principal components (PCs). The first principal component accounts for $49.20 \%$ of the total variance with the second $\mathrm{PC}$ accounting for
$18.90 \%$ and the third for $11.47 \%$ of the total variance (Fig. 3B, $3 \mathrm{C})$. According to the obtained values in principal components, PC 1 particularly represents $\mathrm{SiO}_{2}, \mathrm{TiO}_{2}, \mathrm{Al}_{2} \mathrm{O}_{3}, \mathrm{MgO}, \mathrm{K}_{2} \mathrm{O}$ and $\mathrm{Na}_{2} \mathrm{O}$, while strongly representing $\mathrm{MnO}$ and $\mathrm{CaO}$. PC 2 particularly represents $\mathrm{P}_{2} \mathrm{O}_{5}$, while $\mathrm{Fe}_{2} \mathrm{O}_{3}$ is only strongly represented by both PC 2 and PC 3 . The resulting scatterplot of PC 1 plotted against PC 2 shows relatively scattered cloud datasets for all study sites (Fig. 3A), although confidence ellipses show some grouping. Samples from Hlebine-Velike Hlebine are grouped together, as all the samples are in relative proximity to one another. Samples from the concurrent Virje-Sušine site are grouped and plotted close to the Hlebine-Velike Hlebine samples. Samples of VirjeVolarski Breg dated to the end of the $5^{\text {th }}$ and into the $6^{\text {th }}$ century are plotted distantly from the first two groups and are widely dispersed. The samples from Virje-Sušine $4-5^{\text {th }}$ century are also widely dispersed and overlap all other datasets.

\subsection{Geochemical signature of slags based on trace elements}

In order to define the geochemical signature of the iron slags, 26 trace elements and REEs were selected and normalized to the Upper Continental Crust. Apart for several incompatible elements, slag samples from the Hlebine-Velike Hlebine site have an almost identical geochemical signature. Slight variability can be seen in the total trace and REE contents, however, same characteristic peaks are appearing through all samples. These slag samples are compared with roasted ore samples (BRENKO et al., 2021) from the same site i.e. the same archaeological context interpreted as an iron production workshop and from a nearby and contemporary Hlebine-Dedanovice site. For the majority of the ore samples the patterns have similar shapes and peak heights. Some differentiation in ore geochemistry is noticeable, mostly the trace element contents (Cs-K) (Fig. 4A).

Samples from the Virje-Sušine site are divided in two groups, based on the ${ }^{14} \mathrm{C}$ age determined for charcoal samples from two spatially separate positions (BOTIĆ, 2021; Trench 5 and 7), both of which can be interpreted as iron production workshops, dated to the end of $4^{\text {th }}$ and into the $5^{\text {th }}$ century (Trench 7 ) and to the end of the $6^{\text {th }}$ and into the $1 / 27^{\text {th }}$ century (Fig. 4B). These slag samples are compared with samples of natural and roasted bog iron ore found within the archaeological context (Trench 7) and geological samples of bog iron ore from a near-by location of Novigrad Podravski-Milakov Berek (linear distance 200-300 metres). Differentiation can be noted for the same trace elements (Cs-K), however the general shape of the signature is similar, with same peaks appearing as in the case of Hlebine-Velike Hlebine (Fig. 4B). When comparing these archaeological samples with bog iron ores from Novigrad Podravski major differences are seen in both the trace and REEs of the ores, such as Eu and Sm positive anomalies and a strong enrichment of Ba (Fig. 4B).

The Virje-Volarski Breg site is also divided into two groups based on two positions (Trench 2a and 3, Trench 1) where traces of differently dated iron production workshops were found $\left(5 / 6^{\text {th }}\right.$ century and $8^{\text {th }} / 9^{\text {th }}$ century). The ores used for provenance were discovered in an archaeological context within settlement features (Trench $2 \mathrm{~b}$ ) that can be dated relatively to $8 / 9^{\text {th }}$ centuries and are spatially connected to both positions (linear distance 45251 metres). Geochemical signatures of the ores and slags showed a great resemblance. Very small differentiation is present for $\mathrm{Ba}$ contents between the ore and slag, while other elements have the same peaks and peak heights (Fig. 4C). 

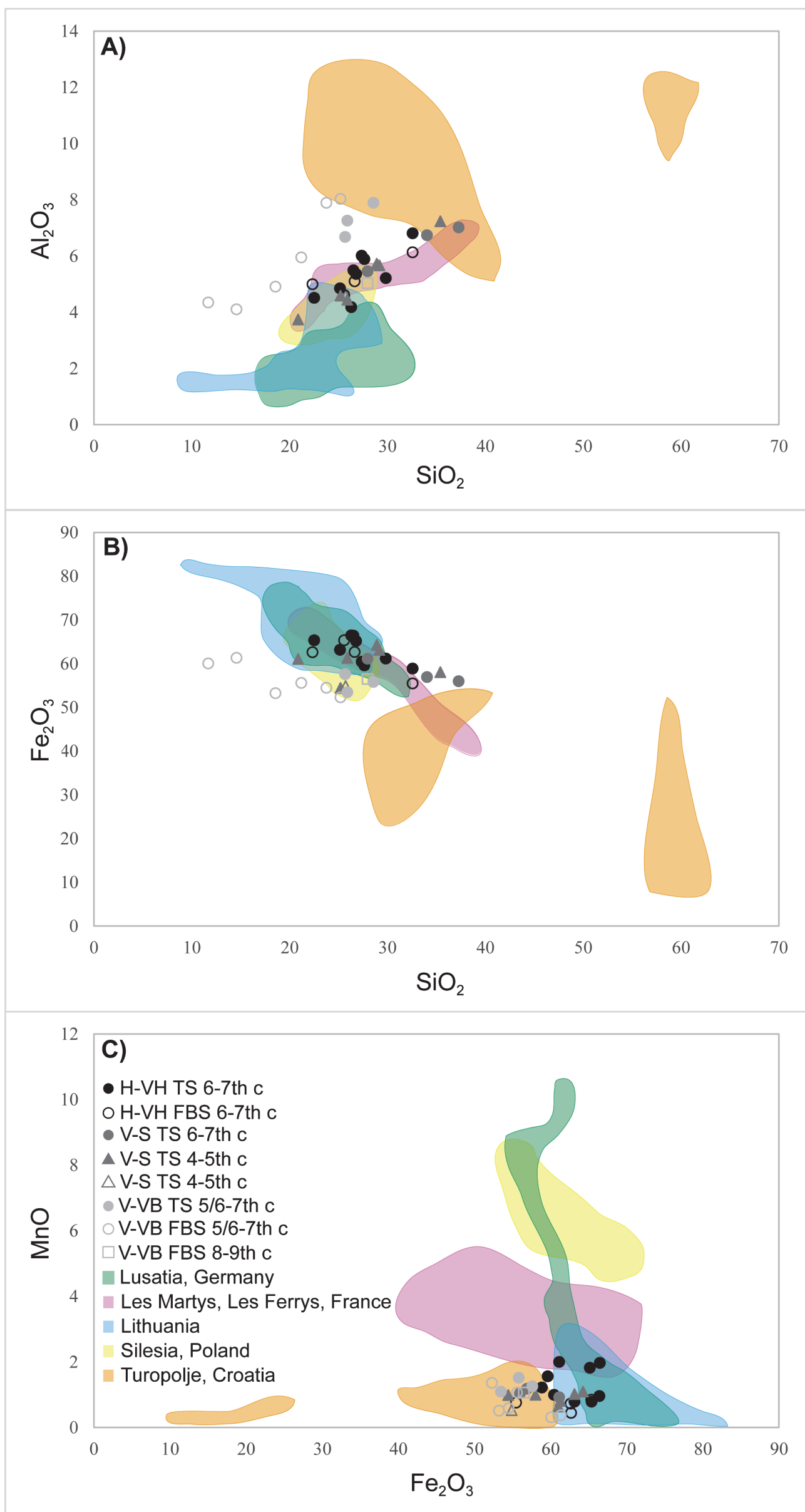

Figure 2. NRC ratios of slag for A) $\left.\mathrm{SiO}_{2} / \mathrm{Al}_{2} \mathrm{O}_{3}, \mathrm{~B}\right) \mathrm{Fe}_{2} \mathrm{O}_{3} / \mathrm{SiO}_{2}$ and C) $\mathrm{Fe}_{2} \mathrm{O}_{3} / \mathrm{MnO}$ compared to other case studies in Croatia and Europe (according to $\mathrm{HEIMANN}$ et al., 2001; COUSTURES et al., 2003; SELSKIENE, 2007; THELEMANN et al., 2017 and NEMET et al., 2018). 

- Hlebine-Velike Hlebine 6-7th tap slag Virje-Sušine 4-5th tap slag Hlebine-Velike Hlebine 6-7th furnace Virje-Sušine 4-5th tap slag - Virje-Sušine 6-7th tap slag
Virje-Volarski Breg 5/6-7th tap slag Virje-Volarski Breg 5/6-7th furnace bottom slag

Virje-Volarski Breg 8-9th furnace bottom slag

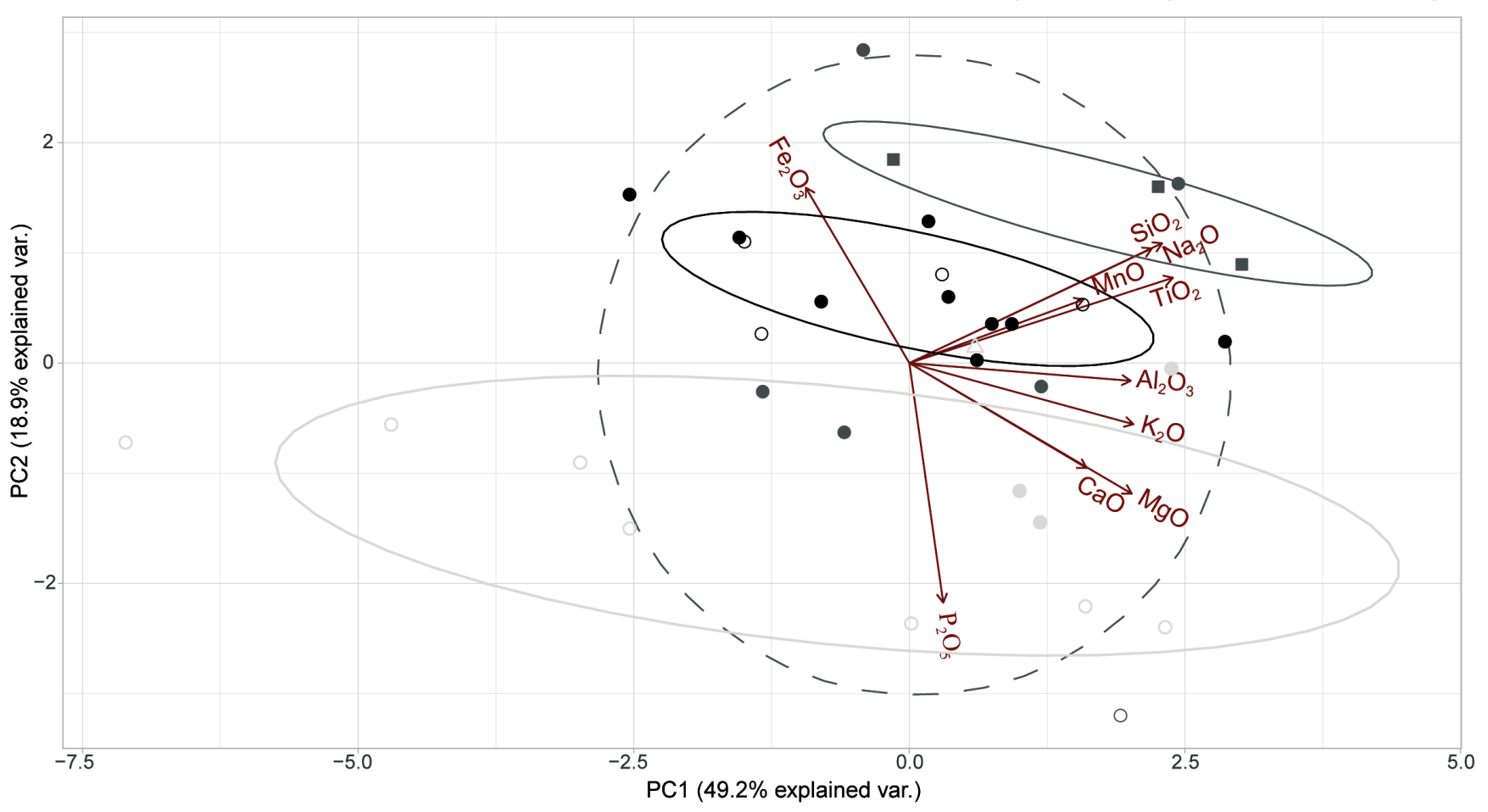

B)

\begin{tabular}{|l|c|c|c|}
\hline \multicolumn{1}{|c|}{ Variable } & Factor 1 & Factor 2 & Factor 3 \\
\hline $\mathrm{SiO}_{2}$ & 0.87 & -0.41 & -0.10 \\
\hline $\mathrm{TiO}_{2}$ & 0.91 & -0.29 & 0.13 \\
\hline $\mathrm{Al}_{2} \mathrm{O}_{3}$ & 0.76 & 0.06 & 0.47 \\
\hline $\mathrm{Fe}_{2} \mathrm{O}_{3}$ & -0.36 & -0.60 & -0.61 \\
\hline $\mathrm{MgO}$ & 0.77 & 0.45 & -0.05 \\
\hline $\mathrm{MnO}$ & 0.60 & -0.22 & -0.39 \\
\hline $\mathrm{CaO}$ & 0.61 & 0.36 & -0.52 \\
\hline $\mathrm{K}_{2} \mathrm{O}$ & 0.77 & 0.21 & 0.01 \\
\hline $\mathrm{Na}_{2} \mathrm{O}$ & 0.84 & -0.39 & 0.02 \\
\hline $\mathrm{P}_{2} \mathrm{O}_{5}$ & 0.12 & 0.83 & -0.33 \\
\hline \multirow{2}{*}{$\begin{array}{c}\text { Principal } \\
\text { component }\end{array}$} & Eigenvalue & $\%$ Total & Cumulative \\
\hline 1 & 4.92 & 49.25 & 49.25 \\
\hline 2 & 1.89 & 18.90 & 68.15 \\
\hline 3 & 1.15 & 11.47 & 79.62 \\
\hline
\end{tabular}

C)

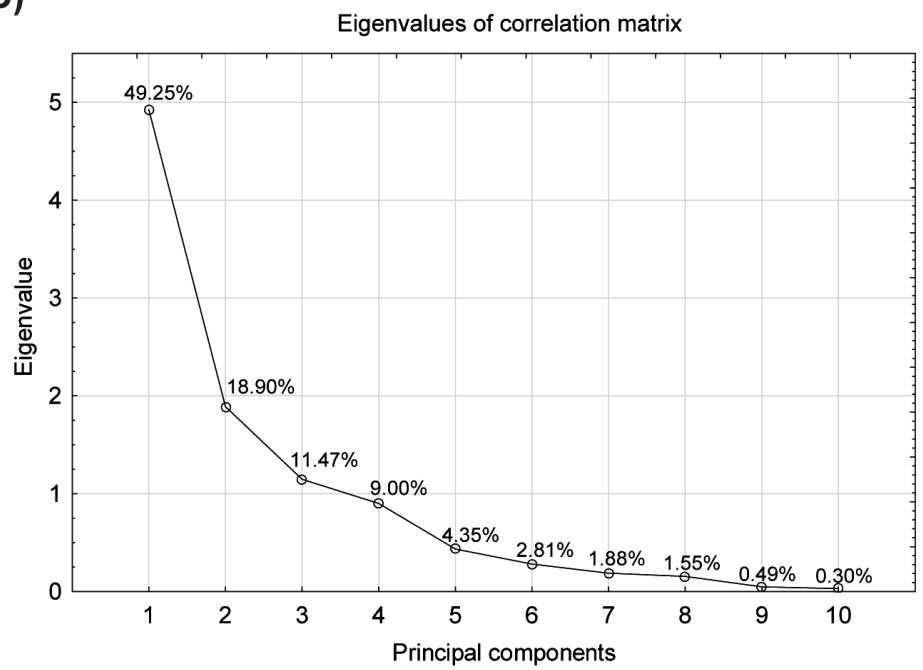

Figure 3. A) PCA scatterplot of PC 1 and PC 2 of the major oxide concentrations, B) Principal component loading and eigenvalues and C) Eigenvalues of covariance matrix plot.

\section{DISCUSSION}

\subsection{Temporal and spatial differences in ore and slag characteristics}

The mineralogical and geochemical composition of the ore, especially the gangue minerals associated with the iron minerals, has a predominant contribution to the mineralogical and geochemical composition of the resulting slags (PORTILLOBLANCO et al., 2020). Fayalite in the slag was formed as the product of the thermal reaction between Fe minerals in the ore (goethite in bog iron ores, haematite in roasted bog iron ores) and quartz during the smelting process, forming the compound $\mathrm{Fe}$ ${ }_{2} \mathrm{SiO}_{4}$ that upon solidification formed olivine phase fayalite (CHARLTON et al., 2012). Studies suggest that the formation temperatures for this process were somewhere between 1100 and $1400{ }^{\circ} \mathrm{C}$ (POLLARD \& HERON, 1996). Wüstite is a situationally occurring mineral in iron slags, mostly occurring in slags from the Virje sites. It is formed when iron oxide occurs in excess amounts (GORDON, 1997), with some studies suggesting that the crystallization starts to occur when the $\mathrm{Fe} / \mathrm{SiO}_{2}$ ratio exceeds 1.5 (KONGOLI \& YAZAWA, 2001; KĄDZIOŁKA et al., 2020). Occurrence of magnetite in some tap slags indicates incomplete reduction during the process, or a secondary formation of magnetite due to the supply of excess air in the smelting system (MANASSE \& MELLINI, 2002). Traces of goethite and haematite can be associated with oxidising conditions (MORTON \& WINDGROOVE, 1969) to which the slags would be exposed af- 

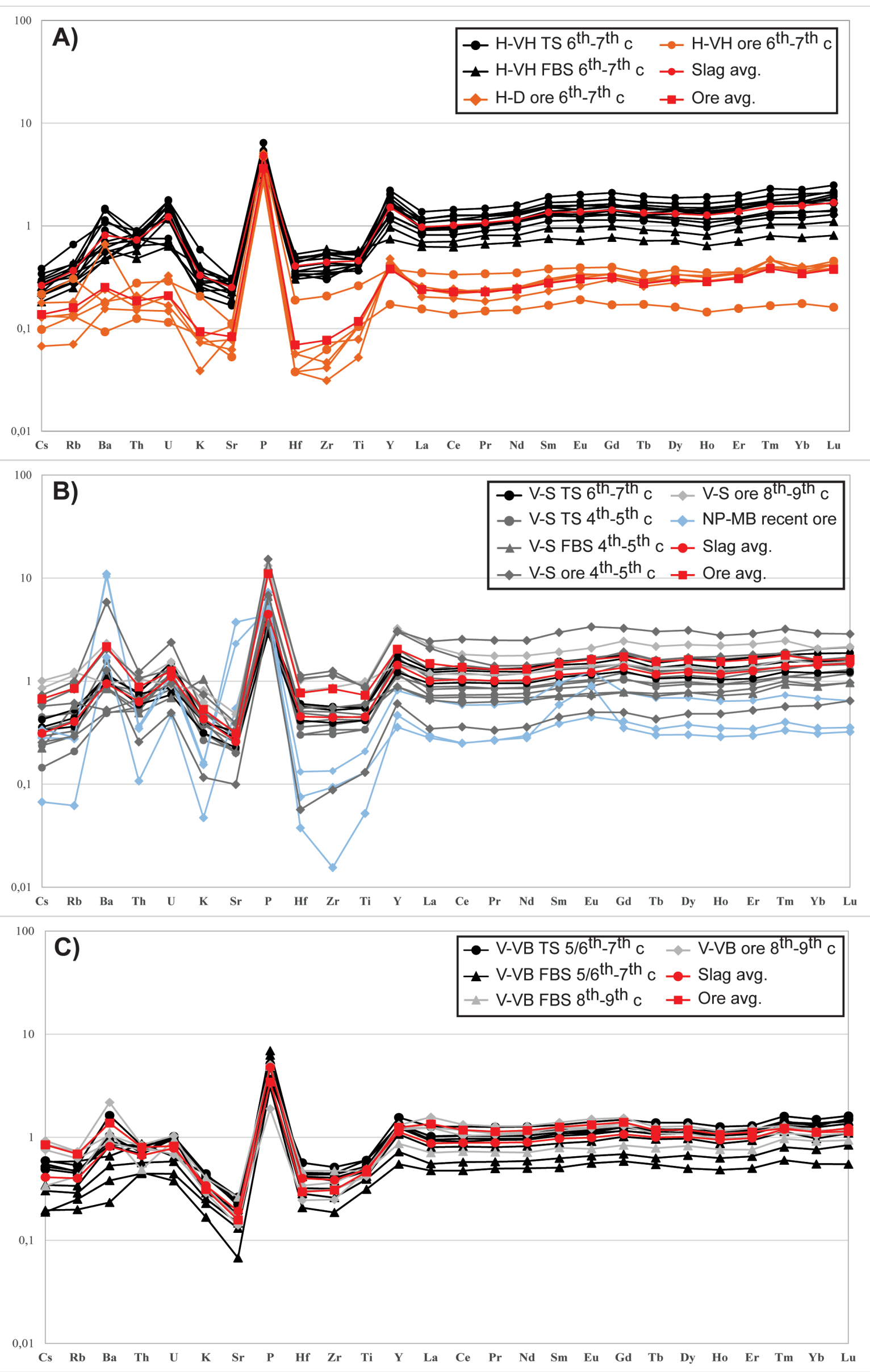

Figure 4. Geochemical signature of iron slags from A) Hlebine-Velike Hlebine, B) Virje-Sušine and C) Virje-Volarski Breg compared to discovered bog iron ores and roasted iron ores from same or nearby study sites. 
ter being removed out of the furnace or through the post-depositional changes, influenced by oxidising conditions and humid soil layers. XRD analysis also revealed the occurrence of an Al-spinel phase (hercynite) in the smelting slags from all sites, with most occurrences from the Virje-Volarski Breg positions. The presence of hercynite indicates that the used ores had elevated contents of aluminium, possibly from Al-phases such as clay minerals and plagioclase. This is in line with previous studies of bog iron ores in the study area (BRENKO et al., 2021), where mineralogical analysis pointed to the occurrence of soil minerals such as clays and feldspars/plagioclase.

The sum of iron, silica and aluminium contents in all locations is mostly around $85-90$ mass. \%, clearly indicating that all samples are metallurgical slags produced during the bloomery iron-making process (BANI-HANI et al., 2012). The geochemical composition of the slag samples shows similarity to other available study cases from Europe (Fig. 2). It is worth noting that chemical data of iron slags in this study is similar to data obtained by NEMET et al. (2019) for slag samples from the neighbouring Turopolje region, especially in regard to $\mathrm{MnO}$ contents, indicating overall similar chemical conditions in the wider area. Upon closer inspection of the major oxide ratios, the regularity and behaviour of major oxides for each site can be detected. Studies (BLAKELOCK et al., 2009; CHARLTON et al., 2012) suggest that certain oxide ratios remain similar between the ore and the slag and could be used to distinguish the usage of different ores between different sites. Previous research regarding possible ore sources for iron production in the Podravina region (BRENKO et al., 2021) indicated higher aluminium contents in bog iron ores from sites within the Virje area (Sušine and Volarski Breg) when compared to the Hlebine area (Velike Hlebine and Dedanovice). Based on the geochemical data, it is highly likely that in each workshop locally available ore from different, probably nearby deposit(s) was used. Iron ore used in the Hlebine-Velike Hlebine site probably contained a lower quantity of gangue minerals (clay minerals and feldspars), therefore having lower Al contents. It is also possible that the ore was pre-processed by washing or that the ore was carefully chosen, while avoiding clayey ore lumps, as was proposed by BRENKO et al. (2021) based on the REE contents. On the other hand, some of the ore used at the VirjeVolarski Breg site, both from the workshop dated to $8 / 9^{\text {th }}$ and to the $5 / 6^{\text {th }}$ centuries, was probably slightly enriched with gangue minerals, which led to an increase of Al in some slags from these positions. Increase in $\mathrm{Al}$ content might be a micro-regional feature typical for the Virje area, although this is not entirely supported by the composition of all slag samples from the workshop dated to $4 / 5^{\text {th }}$ centuries at the Virje-Sušine site. However, archaeological evidence strongly suggests that separation of the ore was carried out at this site as several samples of roasted bog iron ore were found in a waste discarding area (BRENKO et al., 2021) so it could be presumed that the ore was more thoroughly pre-processed and/or more carefully selected. Another option could be that the ores used for individual smelting procedures were not all of the same microregional origin as at the other positions in the Virje area.

This study revealed that the discovered iron ores from the Virje-Sušine and Virje-Volarski Breg sites tend to have increased Mn contents with values sometimes reaching over 20 mass. \%. However, as shown in Table 2, analysed iron slags have low Mn contents, with values around 1 mass. \%. Such low Mn contents imply that ore was processed for both manganese and for clay minerals. However, as some Mn can still be incorporated into the iron bloom (albeit on rare occasions) (NAVASITIS \& SELSKIENĖ, 2007), further investigation into iron bloom geochemistry could reveal whether the ore was truly pre-processed for Mn as well. This could also mean that bog iron ores of different composition were used within a single workshop. The latter would be in line with general bog iron ore characteristics, that can be of very variable quality and overall composition, even if found within the same deposit, and more so in relation to different microenvironmental conditions under which they were formed i.e. different deposits within the same region. A sign of inconsistency of overall characteristics of used ore or the way that the ore was smelted can be seen in the wide dispersion of slag samples from the Late Antiquity, the Virje-Sušine workshop $\left(4 / 5^{\text {th }}\right.$ centries) as well as from the workshop on the Virje-Volarski Breg site belonging to the end of $5 / 6^{\text {th }}$ century (Fig. 3 ).

\subsection{Provenance studies}

Numerous studies have been carried out, in an attempt to establish the relationship between possible iron ore and iron slags (PLEINER, 1967; DEVOS et al., 2000; SCHWAB, 2006; BLAKELOCK et al., 2009), which is not always unbiased, due to numerous reasons. The ore used in iron smelting accounts for around $77-100 \%$ of the chemical composition of slag, and therefore, slag derives the majority of its bulk composition from ore, with part of the composition depending on the furnace structural ceramics, fuel and flux material (CREW, 2000). This can be reflected in the frequency distribution charts of major element NRC ratios. COUSTURES et al. (2003) determined that although clay and charcoal alter the trace element composition of the slag, the variability is so insignificant that the correlation coefficient of the two is acceptable. Previous study (BRENKO et al., 2021) suggested that it is possible to determine the type of used ore by comparing the geochemical signature of rare earth and trace elements between samples of bog iron ore and archaeological samples of roasted bog iron ore. However, the method of clustering and correlation was used on archaeological samples that were exposed to an average temperature between 550 and $600{ }^{\circ} \mathrm{C}$, with a maximum spike in temperature of $1038^{\circ} \mathrm{C}$ (KARAVIDOVIĆ, 2020), where limited mobility was recognized between rare earth and trace elements. As iron slags are formed at temperatures much higher than roasted ores, some degree of mobility and fractionation in trace elements is to be expected, even in the case when considering immobile elements such as REEs or trace elements (LINTHEWAS \& SETIAWAN, 2018). Slight differentiation of rare earth and trace element contents can be noticed in all sites when comparing the signature of tap slags and furnace bottom slags. Based on the diagrams in Fig. 4, it seems that tap slags have slightly higher contents of REEs and trace elements than furnace bottom slags which can be explained by the thermodynamic behaviour of the incompatible elements, as they are more likely to separate to a more liquid phase, such as the tap slag. Therefore, the type of analysed slag inevitably holds some degree of influence on the overall geochemical signature, at least content related.

The ideal case in determining the type of used ore in an archaeological context would be to compare the ore found in the same context as the slag itself, which is rarely possible due to the nature of the archaeological record where used raw materials are often not discovered. However, in the case of the Hlebine-Velike Hlebine, slags could be compared to two archaeological samples of roasted ore from the same site interpreted as an iron production workshop, and four samples of roasted ore from a close-by 
concurrent Hlebine-Dedanovice site. The total contents of trace and REEs between the ore and slag samples differ in favour of the slag that can be attributed to iron depletion from the ore to the slag (DESAULTY et al., 2009). Analysed iron slags have lower $\mathrm{Fe}$ contents than the ore samples used for provenance (BRENKO et al., 2021). However, when the same elements are plotted on a multielemental diagram, they exhibit characteristic peaks that could indicate the provenance of the slag material. The first noticeable peak is the high positive enrichment of phosphorus in both ores and slags. Studies often indicate that bog iron ores contain significant contents of $\mathrm{P}_{2} \mathrm{O}_{5}$ (STOOPS, 1983; LANDUYDT, 1990; TÖRÖK \& THIELE, 2013; THELEMANN et al., 2017). This is a strong indication in the usage of bog iron ores for iron production in the study area. Trace elements such as $\mathrm{Cs}, \mathrm{Rb}$, $\mathrm{K}$ and $\mathrm{U}$ are often observed in variable contents in the soils (MAES et al., 1999; GINGELE \& DECKER, 2007; ZAUNBRECHER et al., 2015; FULLER et al., 2015). Such behaviour was also detected through soil profiles in the Podravina region (BRENKO et al., 2020). Therefore, some variability in the geochemical signatures of bog iron ores formed in such soils, and accompanying slags is to be expected, especially if the soils are subjected to constant redox changes such as in the Podravina region due to fluctuation of groundwater. The REEs (Y-Lu) part of the diagram is almost identical in shape and patterns in both ores and slags, indicating a similar genetic origin between them.

Bog iron ores from the archaeological context of the VirjeSušine site and ores found in a geological context from a nearby Novigrad Podravski-Milakov Berek site are compared with the iron slags from Virje-Sušine. It can be seen that the geochemical signature of slag samples found in the context of the workshop dated between the end of $4^{\text {th }}$ and the beginning of $5^{\text {th }}$ century, and samples from another workshop dated between the end of the $6^{\text {th }}$ and into $7^{\text {th }}$ century show slight discrepancies to one another. This suggests variety in the ore used, most notably the clay minerals, that could be due to exploitation of different deposits or different ore-processing activities. Additionally, the geochemical signature of the compared ores belonging to the same archaeological context, the workshop at Virje-Sušine dated to $4 / 5^{\text {th }}$ centuries, also shows pattern variability. A possible explanation for this is found within the archaeological context as all of the ore samples were found in layers of smelting debris, implying that these ores were possibly not meant to be used, due to their inadequate metallurgical characteristics as proposed by BRENKO et al. (2021). However, a distinctive positive phosphorus peak is again present in both ores and slag, indicating that bog ores were used as the primary ore source. Based on the mineralogy of the analysed bog iron ores from the study site and nearby Novigrad Podravski site, differentiation of the used ores can be achieved by observing their $\mathrm{Ba}$ and $\mathrm{Sr}$ contents. Previous study (BRENKO et al., 2021) suggests that $\mathrm{Ba}$ in the ore correlates well with the $\mathrm{Mn}$ amorphous phase, while an Eu anomaly occurs due to the substitution of $\mathrm{Eu}^{3+}$ with $\mathrm{Ca}^{2+}$ in the calcite structure (HELLEBRANDT et al., 2017), a mineral that was discovered occurring in the ore samples from that location. This implies that Mn-rich ores were most likely not used in the individual smelting episodes represented in selected samples. This anomaly also provides evidence to propose that the composition of bog iron ores from the same regional origin can vary significantly in relation to the location of the deposit and presumably the period when bog iron ore was formed.

The clearest situation in terms of provenance can be seen in the Virje-Volarski Breg site. The ore samples were found in fea- tures within a settlement context dated to the $8 / 9^{\text {th }}$ centuries, that is spatially connected to the concurrent iron production workshop from which the analysed slag originates (Trench 1). This implies that the ore discovered at this location was used for iron smelting and production on the same site. All three ore samples have an almost identical geochemical signature to the signature of the slags, with all the characteristic peaks as indicated by the average ore and average slag lines on Fig. 4C. When compared to the slag samples from the workshop dated to the $5 / 6^{\text {th }}$ centuries, a similar degree of overlapping geochemical signatures is seen. Here, some slag samples show depletion in overall contents while others are of almost identical signature. Some differentiation can be noticed in the Ba contents, but these can also be attributed to slight variations in the Mn contents of the bog iron ore, as previous study (BRENKO et al., 2021) showed correlation between $\mathrm{Mn}$ and $\mathrm{Ba}$ in bog iron ores.

\section{CONCLUSION}

In the study area of the Podravina region, iron was produced via the direct process i.e. bloomery smelting in the Late Antiquity and the Early Middle Ages, as excavated archaeological sites suggest. The analysed slag is divided into two groups based on macroscopic analysis: tap slag and furnace bottom slag. Both slag types are characterized by fayalite as the main Fe mineral phase. Occurrences of other Fe minerals, such as wüstite, haematite and magnetite imply some variability in the smelting processes. Overall, the major oxide composition of analysed slags suggests differentiation for some NRC ratios, such as slight $\mathrm{Al}_{2} \mathrm{O}_{3}$ differentiation at the Virje-Volarski Breg site. This is related to a higher clay content in the ores used within the Virje-Volarski Breg workshops but as samples of slag and ores originate from differently dated sites, these characteristics could be connected to the usage of iron ores that were formed under similar micro-environmental conditions, presumably in the surroundings of the Virje site.

An attempt was made to determine the provenance of iron slags in the Podravina region, through the analysis of trace and rare earth elements in both slags and locally discovered ores. Methods included normalization and plotting of selected elements, forming geochemical signatures for both ores and slags, that were then further compared and analysed. Specific peaks, such as the positive P peak implies the usage of locally discovered bog iron ore as the main raw material. In the case of the Virje-Volarski breg site, identical shapes and peak heights undeniably point to the usage of bog iron ore as the main raw material. Differentiation and inconsistency can be seen in signatures from Hlebine-Velike Hlebine and Virje-Sušine, most notably in the trace element contents. Such differentiation stems from trace elements that are incorporated into clay minerals, such as $\mathrm{Cs}, \mathrm{Rb}$ and $\mathrm{K}$, questioning their usability as such in the provenance studies. However, general shape of the signatures points toward bog iron ore usage on Hlebine-Velike Hlebine and Virje-Sušine sites.

Differentiation between the potential location of the deposits and/or time when the ores were formed can also be presumed from the ores signature, as the ore samples from the archaeological context of Virje-Sušine site and the geological context from the nearby Novigrad Podravski-Milakov Berek site exhibited a different geochemical signature, most notably in regard to Ba content. Therefore, study indicates the possibility of discrimination in the usage of ores based on their micro-locational or temporal provenance, by detailed mineralogical analysis followed by geochemical analysis. 


\section{ACKNOWLEDGMENT}

This work has been fully supported by the Croatian Science Foundation under the project TransFER - Iron production along the Drava River in the Roman period and the Middle Ages: Creation and transfer of knowledge, technologies and goods (Grant No. 5047). We would like to thank our project partners from The Institute of Archaeology and City Museum of Koprivnica, whose continuous fieldwork led to archaeological discoveries of iron production culture in the Podravina region. We would also like to thank Stanko Ružičić, $\mathrm{PhD}$, whose comments helped improve the quality of this manuscript.

\section{Dataset statement}

The data that supports the finding of this study is available from the corresponding author upon reasonable request.

\section{REFERENCES}

BANI-HANI, M., ABD-ALLAH, R. \& EL-KHOURI, L. (2012): Archaeometallurgical finds from Barsinia, Northern Jordan: Microstructural characterization and conservation treatment.- J. Cult. Herit., 13, 314-325. doi: 10.1016/j.culher.2011.12.005

BAŠIĆ, F. (2013): The Soils of Croatia (1st ed.).-- Springer Science+Business Media Dordrecht. doi: 10.1007/978-94-007-5815-5

BLAKELOCK, E., MARTINÓN-TORRES, M., VELDHUIJZEN, H.A. \& YOUNG, T. (2009): Slag inclusions in iron objects and the quest for provenance: an experiment and a case study. - J. Archaeol. Scie., 36, 1745-1757. doi: 10.1016/j.jas.2009.03.032

BOTIĆ, K. (2021): Absolute dating of Virje and Hlebine sites.- In: SEKELJ IVANČAN, T. \& KARAVIDOVIĆ, T. (eds.): Interdisciplinary Research into Iron Metallurgy along the Drava River in Croatia - The TransFER Project, Oxford: Archaeopress, 92-100. doi: 10.32028/9781803271026-5

BRENKO, T., BOROJEVIĆ ŠOŠTARIĆ, S., KARAVIDOVIĆ, T., RUŽIČIĆ, S. \& SEKELJ IVANČAN, T. (2021): Geochemical and mineralogical correlations between the bog iron ores and roasted iron ores of the Podravina region, Croatia.Catena, 204, 105353. doi: 10.1016/j.catena.2021.105353

BRENKO, T., BOROJEVIĆ ŠOŠTARIĆ, S., RUŽIČIĆ, S. \& SEKELJ IVANČAN, T. (2020): Evidence for the formation of bog iron ores in the soils of the Podravina region, NE Croatia: Geochemical and mineralogical study.- Quatern. Int., 536, 13-29. doi: 10.1016/j.quaint.2019.11.033

BRKIĆ, Ž. \& BRIŠKI, M. (2018): Hydrogeology of the western part of the Drava Basin in Croatia.- J. Maps., 14, 173-177. doi: 10.1080/17445647.2018.1445043

BRKIĆ, Ž., LARVA, O. \& URUMOVIĆ, K. (2010): The quantitative status of the groundwater in alluvial aquifers in northern Croatia.- Geol. Croat., 63, 283-298. doi: $10.4154 /$ GC.2010.23

CHARLTON, M.F., CREW, P., REHREN, TH. \& SHENNAN, S.J. (2010): Explaining the evolution of ironmaking recipes-an example from northwest Wales. - J. Anthropol. Archaeol., 29, 352-367. doi: 10.1016/j.jaa.2010.05.001

CHARLTON, M.F., BLAKELOCK, E., MARTINÓN-TORRES, M. \& YOUNG, T. (2012): Investigating the production provenance of iron artifacts with multivariate methods.- J. Archaeol. Sci., 39, 2280-2293. doi: 10.1016/j.jas.2012.02.037

COUSTURES, M.P., BÉZIAT, D. \& TOLLON, F. (2003): The use of trace element analysis of entrapped slag inclusions to establish ore - bar iron links: examples from two Gallo-roman iron-making sites in France (Les Martys, Montagne Noire, and Les Ferrys, Loiret).- Archaeometry, 45, 599-613. doi: 10.1046/j.1475-4754.2003.00131.x

CREW, P. (2000): The influence of clay and charcoal ash on bloomery slags.- In TIZZONI, C.C. \& TIZZONI M. (eds.): Iron in the Alps: Deposits, Mines and Metallurgy from Antiquity to the XVI Century, Bienno, p. 38-48.

DESAULTY, A-M., DILLMANN, P., L'HÉRITIERA, M., MARIET, C., GRATUZE, B., JORON, J-L. \& FLUZIN, P. (2009): Does it come from the Pays de Bray? Examination of an origin hypothesis for the ferrous reinforcements used in French medieval churches using major and trace element analyses.- J. Archaeol. Sci., 36, 2445-2462. doi: 10.1016/j.jas.2009.07.002

DEVOS, W., SENN-LUDER, M., MOOR, C. \& SALTER, C. (2000): Laser ablation inductively coupled plasma mass spectrometry (LA-ICP-MS) for spatially resolved trace analysis of early-medieval archaeological iron finds.- Int. J. Anal. Chem., 366, 873-880. doi: 10.1007/s002160051588

DILLMANN, P. \& L'HÉRITIER, M. (2007): Slag inclusion analyses for studying ferrous alloys employed in French medieval buildings: supply of materials and diffusion of smelting processes.- J. Archaeol. Sci, 34/11, 1810-1823. doi: 10.1016/j. jas.2006.12.022

FULLER, A.J., SHAW, S., WARD, M.B., HAIGH, S.J., MOSSELMANS, F.W., PEACOCK, C.L. STACKHOUSE, S., DENT, A.J., TRIVEDI, D. \& BURKE, I.T.
(2015): Caesium incorporation and retention in illite interlayers.- Appl. Clay Sci., 108, 128-134. doi: 10.1016/j.clay.2015.02.008

GINGELE, F.X. \& DE DECKKER, P. (2005): Clay mineral, geochemical and Sr-Nd isotopic fingerprinting of sediments in the Murray-Darling fluvial system, southeast Australia.-Aust. J. Earth Scie., 52, 965-974. doi: 10.1080/08120090500302301

GORDON, R.B. (1997): Process deduced from ironmaking wastes and artefacts.- J. Archaeol. Sci., 24, 9-18. doi: 10.1006/jasc.1995.0092

HEAD J. M. (2019). Formal subdivision of the Quaternary System/Period: Present status and future directions.- Quatern. Int., 500, 32-51. doi: 10.1016/j.quaint.2019.05.018

HEIMANN, R.B., KREHER, U., SPAZIER, I. \& WETZEL G. (2001): Mineralogical and chemical investigations of bloomery slags from prehistoric (8th century BC to 4th century AD) iron production sites in Upper and Lower Lusatia, Germany.Archaeometry, 43, 227-252. doi: 10.1111/1475-4754.00016

HELLEBRANDT, S.E., HOFMANN, S., JORDAN, N., BARKLEIT, A. \& SCHMIDT, M. (2017): Incorporation of Eu(III) into Calcite under Recrystallization conditions.- Sci. Rep-UK., 6, 33137. doi: 10.1038/srep33137

HORST-MADSEN, L. \& BUCHWALD, V.F. (1999): The characterisation and provenancing of ore, slag and iron from the Iron Age settlement in Snorup.- The Journal of the Historical Metallurgy Society, 33/2, 57-67.

KACZOREK, D. \& SOMMER, M. (2003): Micromorphology, chemistry and mineralogy of bog iron ores from Poland.- Catena, 54, 393-402. doi: 10.1016/S03418162(03)00133-4

KĄDZIOŁKA, K., PIETRANIK, A., KIERCZAK, J., POTYSZ, A. \& STOLARCZYK, T. (2020): Towards better reconstruction of smelting temperatures: Methodological review and the case of historical K-rich Cu-slags from the Old Copper Basin, Poland.- J. Archaeol. Sci., 118, 105142. doi: 10.1016/j.jas.2020.105142

KARAVIDOVIĆ, T. (2020): Rekonstrukcija postupka prženja rude: eksperimentalni pristup.- In: VITEZOVIĆ, S., ANTONOVIĆ, D. \& ŠARIĆ, K. (eds.):Aktuelna interdisciplinarna istraživanja tehnologije u arheologiji Jugoistočne Europe, Zbornik radova prvog skupa sekcije za arheometriju, arheotehnologiju i eksperimentalnu arheologiju Srpskog arheološkog društva, [Current interdisciplinary technology in archaeology research of south-eastern Europe, Proceedings from first meeting of archaeometry, archaeotechnology and experimental archaeology of Serbian Archaeological Society], 130-137.

KONGOLI, F. \& YAZAWA, A. (2001): Liquidus surface of $\mathrm{FeO}-\mathrm{Fe}_{2} \mathrm{O}_{3}-\mathrm{SiO}_{2}-\mathrm{CaO}$ slag containing $\mathrm{Al}_{2} \mathrm{O}_{3}, \mathrm{MgO}$, and $\mathrm{Cu}_{2} \mathrm{O}$ at intermediate oxygen partial pressures.Metall. Mater. Trans. B., 32, 583-592. doi: 10.1007/s11663-001-0114-7

KOPIĆ, J., LOBOREC, J. \& NAKIĆ, Z. (2016): Hydrogeological and hydrogeochemical characteristics of a wider are of the regional well field Eastern Slavonia Sikirevci.- The Mining-Geological-Petroleum Bulletin, 31, 47-66. doi: 10.17794/ rgn.2016.3.4

LANDUYDT, C.J. (1990): Micromorphology of iron minerals from bog ores of the Belgian

Campine area.- Dev. Soil Sci., 19, 289-294. doi: 10.1016/S0166-2481(08)70340-4.

LINTJEWAS, L. \& SETIAWAN, I. (2018): Mobility of rare earth element in hydrothermal process and weathering product: a review.- IOP Conf. Series: Earth and Environmental Science, 118. doi: 10.1088/1755-1315/118/1/012076

LÓCZY, D., DEZSÖ, J., CZIGÁNY, S., GYENIZSE, P., PIRKHOFFER, E. \& HALÁSZ, A. (2014): Rehabilitation potential of the Drava River floodplain in Hungary.- In: 2nd International Water Resources and Wetlands. Conference Paper.

MANASSE, A. \& MELLINI, M. (2002): Chemical and textural characterization of medieval slags from the Massa Marittima smelting sites (Tuscany, Italy).- J. Cult. Herit., 3, 187-198. doi: 10.1016/S1296-2074(02)01176-7

MAES, E., ISERENTANT, A., HERBAUTS, J. \& DELVAUX, B. (1999): Influence of the nature of clay minerals on the fixation of radiocaesium traces in an acid brown earth-podzol weathering sequence.- Eur. J. Soil Sci., 50, 117-125. doi: 10.1046/j.1365-2389.1999.00224.x

MORTON, G. R., \& WINGROVE, J. (1969): Constitution of bloomery slags, part 1: Roman.- J. Iron Steel I., 207, 1556-1564.

NAVASAITIS, J. \& SELSKIENE், A. (2007): Metallographic Examination of Cast Iron Lump Produced in the Bloomery Iron Making Process.- Mat. Sci., 13/2, 167-173.

NAVASAITIS, J., SELSKIENĖ, A. \& ŽALDARYS, G. (2010): The Study of Trace Elements in Bloomery Iron.- Mater. Sci.+, 16/2, 113-118.

NEMET, I., RONČEVIĆ, S., BUGAR, A., ZUBIN FERRI, T. \& PITAREVIĆ, L. (2018): Classification analysis of archaeological findings from early-iron production (Turopolje region, NW Croatia) based on multi-analytical profiling.- J. Anal. Atom. Spectrom., 33, 2053-2061. doi: 10.1039/C8JA00202A

PLEINER, R. (1967): Die Technologie des Schmiedes in der Großmährischen Kultur.Slovenská Archeológia, 15/1, 77-188.

PLEINER, R. (2000): Iron in Archaeology. The European Bloomery Smelters.- Archeologický ústav AV CR, Prague, 400 p.

POLLARD, M. \& HERON, C. (1996): Archaeological Chemistry.- Royal Society of Chemistry, Cambridge, 456 p. doi: 10.1039/9781847550156

PORTILLO-BLANCO, H., CRUZ ZULUAGA, M., ANGEL ORTEGA, L., ALONSOOLAZABAL, A., CEPEDA-OCAMPO, J.J. \& MARTINEZ SALCEDO, A. (2020): Mineralogical Characterization of Slags from the Oiola Site (Biscay, Spain) 
to Assess the Development in Bloomery Iron Smelting Technology from the Roman Period to the Middle Ages.- Minerals-Basel, 10, 321. doi: 10.3390/ $\min 10040321$

RAMANAIDOU, E. AND WELLS, M.A. (2014): Sedimentary Hosted Iron Ores.- In: HOLLAND, H.D. \& TUREKIAN, K.K. (eds.): Treatise on Geochemistry 2nd ed., 313-355. Elsevier, Oxford. doi: 10.1016/B978-0-08-095975-7.01115-3

ROLLINS, H. (1993): Using geochemical data (1st ed.).- London, United Kingdom, $384 \mathrm{p}$.

RUDNICK, R.L. \& GAO, S. (2003): Composition of the continental crust.- Treatise on Geochemistry, 3, 1-64. doi: 10.1016/B0-08-043751-6/03016-4

SCHWAB, R., HEGER, D., HÖPPNER, B. \& PERNICKA, E. (2006): The provenance of iron artefacts from Manching: a multi-technique approach.- Archaeometry, 48 433-452. doi: 10.1111/j.1475-4754.2006.00265.x

SEKELJ IVANČAN, T. \& TKALČEC, T. (2018): Settlement Continuity at Sušine Site near Virje (North Croatia) throughout the Middle Ages.- Konštatínove listy 11, 35-66. doi: 10.17846/CL.2018.11.2.35-66

SEKELJ IVANČAN, T. \& KARAVIDOVIĆ, T. (2021): Archaeological Record of Iron Metallurgy Along the Drava River.- In: SEKELJ IVANČAN, T. \& KARAVIDOVIĆ, T. (eds.): Interdisciplinary Research into Iron Metallurgy along the Drava River in Croatia - The TransFER Project, Oxford: Archaeopress, 43-91. doi: 10.32028/9781803271026-4

SELSKIENĖ, A. (2007): Examination of smelting and smithing slags formed in bloomery iron-making process.- Chemija, 18, 22-28.
STOOPS, G. (1983): SEM and light microscopic observations of minerals in bog-ores of the Belgian Campine.- Geoderma, 30, 179-186. doi: 10.1016/00167061(83)90065-4.

THELEMANN, M., BEBERMEIER, W., HOELZMANN, P. \& LEHNHARDT, E. (2017): Bog iron ore as a resource for prehistoric iron production in Central Europe - A case study of the Widawa catchment area in eastern Silesia, Poland.- Catena, 149, 474-490. doi: 10.1016/j.catena.2016.04.002

TÖRÖK, B. \& THIELE, A. (2013): Extracting phosphoric iron under laboratorial conditions smelting bog iron ores.- In: IOP Conference Series: Materials Science and Engineering, Volume 47, 2nd International Conference on Competitive Materials and Technological Processes (IC-CMTP2) 8-12 October 2012, Miskolc-Lillafüred, Hungary, 012034. doi: 10.1088/1757-899X/47/1/012034

VALENT, I. (2021): Archaeological Finds of Metallurgical Activities on the Territory of the River Drava Basin During Iron Age and Antiquity.- In SEKELJ IVANČAN, T., KARAVIDOVIĆ, T., TKALČEC, T., KRZNAR, S. \& BELAJ, J. (eds.), Secrets of iron - from raw material to an iron object, Proceedings of the 7th International Scientific Conference on Mediaeval Archaeology of the Institute of Archaeology, Serta Instituti Archaeologici, Zagreb: Institut za arheologiju.

ZAUNBRECHER, L.K., CRAWFORD ELLIOTT, W., WAMPLER, J.M., PERDRIAL, N. \& KAPLAN, D.I. (2015): Enrichment of Cesium and Rubidium in Weathered Micaceous Materials at the Savannah River Site, South Carolina.- Environ. Sci. Technol., 49, 4226-4234. doi: 10.1021/es5054682 